\title{
Popular Theatre - Highbrow or Lowbrow?
}

\section{JON NYGAARD}

\begin{abstract}
For 13 years, from 1851 to 1864 , Ibsen worked full time at the Norwegian theatres in Bergen and Christiania (Oslo) as a stage director and theatre manager. Ibsen's period in the theatre and the repertory he staged have seldom enjoyed much attention in scholarly research. The reason for this has been that the repertory lbsen staged has been seen as vulgar and lowbrow, and Ibsen's period in the theatre has almost unanimously been seen as a waste of time. The general understanding has been that Ibsen's development as an artist had been much faster if he had been working with a highbrow repertory of serious drama.

Contrary to this established opinion I will contribute to the discussion of popular theatre as highbrow or lowbrow by presenting the production $A$ Caprice (En Kaprice) by Erik Bøgh, staged by Henrik Ibsen at the Norwegian Theatre in Christiania (Oslo). It premiered 7 September 1859 and then ran for another thirty-five performances during the 1859-60 season. The total number of attendances was more than 30.000 . In relation to the population of the town of 42.000 , it was about $2 / 3$ or $67 \%$. This is the by far largest box-office success in Norwegian theatre history. No wonder that Ibsen scholars generally have understood $A$ Caprice as the ultimate example of the unholy trade lbsen was forced into as a theatre manager. According to Michael Meyer Ibsen for the only time in his life "rebuked for truckling to the box-office" (Meyer 1971, 166). The contemporary criticism in Morgenbladet (Nr. 278, 9.10.1859) claimed that Ibsen was declining the Norwegian Theatre in Christiania into a kind of amusement ground for the lower classes.

I will, however, present $A$ Caprice as the summit of Ibsen's theatrical career and underline that both this and other dance productions staged by lbsen in this period, were not at all amusement for the lower classes but on the contrary important expressions of his artistic creativity and development - and actually a highbrow performance presented for an upper class audience.
\end{abstract}

\section{KEYWORDS}

Henrik Ibsen; Nineteenth-century Norwegian theatre; Audience and class; En Kaprice. 



\section{Popular Theatre - Highbrow or Lowbrow}

\section{INTRODUCTION}

In this article, I will contribute to the discussion of the relevance of the categories 'lowbrow' and 'highbrow' by examining the production A Caprice (En Kaprice) by the Danish playwright Erik Bøgh, staged by Henrik Ibsen at the Norwegian Theatre in Christiania (Kristiania Norske Theater) ${ }^{1}$ in 1859. In another context, I have, together with the dance historian Elizabeth Svarstad, discussed the content of the performance to support the claim that this production was the summit of Ibsen's theatrical career and, because of the special dances presented in the performance, it was not at all mere amusement for the lower classes, but instead an expression of artistic creativity and development. ${ }^{2}$

In this article, I will, in a historical and social context, try to explain the sensational fact that Ibsen's production of $A$ Caprice, after it premiered on 7 September 1859 , actually ran for another thirty-seven performances, ${ }^{3}$ reaching a total audience number of above 30000 . In relation to the population of the city of Christiania in 1859 , of 42000 , this audience number amounts to about $2 / 3$ or

1 From 1624 until 1924, the official name for Oslo was Christiania. However, due to political language reasons, the Norwegian Theatre used the Norwegian form Kristiania with a $\mathrm{K}$ and not the Danish Christiania with a Ch.

2 Svarstad and Nygaard 2016.

3 Anker 1956. 
$67 \%$ of the population. This is by far the largest box-office success in the history of regular theatres in Norway. No wonder that the production of $A$ Caprice has been understood as the ultimate example of "The Unholy Trade" Ibsen was forced into as a theatre manager. According to Audhild Lund, Ibsen's contemporary critics also claimed that Ibsen, with this production, was degrading the Norwegian Theatre in Christiania into a kind of amusement ground catering to the lower classes. ${ }^{5} \mathrm{My}$ aim will be to explain that the high attendance was not because it was a lowbrow production for a lower-class audience, but that it was actually presented for an upper-class audience. The concepts 'highbrow' and 'lowbrow' are therefore misleading if applied without a relation to the context.

To understand the context of Ibsen's years in the theatre we have to take into consideration Norwegian theatre history, the reason for the founding of a Norwegian Theatre in Christiania, the values and positions represented by the theatre's founders and later board members, and, most importantly, the development of the city of Christiania and its theatre audience.

My main point will be that there is no reason to claim that $A$ Caprice was amusement for the lower classes because, as I will discuss further below, the lower classes were not really established in Christiania in 1859. The lower classes, in the meaning of a large working class, urban population, only started to emerge in Christiania after 1859, particularly at the end of the nineteenth century. Thus, A Caprice was amusement for the upper classes. To underline this point, I will rely on the theories of Pierre Bourdieu and his critique of the traditional, Kantian understanding of art and taste.

\section{'HIGBROW' VERSUS 'LOWBROW' - KANT VERSUS BOURDIEU}

In the "Postscript: Towards a 'Vulgar' Critique of 'Pure' Critiques" in his book Distinction: A Social Critique of the Judgment of Taste, Bourdieu underlines the distinction between the traditional or Kantian understanding of art as pure and disinterested, which should accordingly be regarded at a noble distance - and,

4 Meyer 1971. This is the title for the chapter covering Ibsen's first years in the theatre, 1851-1854.

5 Lund 1925, 55. 
on the other hand, the immediate involvement and enjoyment of it. ${ }^{6}$ According to the Kantian understanding, the value, or quality of art, is associated with seriousness, discrimination, fastidiousness - in opposition to the easy, light, and immediate. To gain access to what we generally understand as 'highbrow', or the pure art and the purity of art, the recognizing subject, according to Kant, had to be released from all inclinations and needs. Art is, in other words, a peculiar sphere independent of worldly interests - and the artist creates the work of art exclusively from his inner imperative.

Bourdieu claims, however, that this refined understanding of art denies the facts he emphasises in Distinction, that taste, experience, and the evaluation of art is closely related to social conditions and social classes. Consequentially, we also have to discuss the relevance of the concepts 'highbrow' and 'lowbrow' in relation to social conditions and social classes. Highbrow includes a relation to the intellectual, classical elite and their understanding of 'high culture'. Lowbrow is from the same perspective 'low culture' related to the popular, non-academic 'tasteless masses' excluded from academic scholarship.

This means, as Bourdieu underlines, that all expressions attracting a large audience are immediately understood as light and of lower quality and importance than 'serious' art. This again is the explanation as to why lbsen's staging of $A$ Caprice, both by his contemporary critics and later by Ibsen scholars, has been evaluated to be of low quality because it attracted a large audience, and this audience has again immediately and uncritically been understood to be from the lower classes. This understanding is, however, neither based on the actual quality of the performance, nor, as will be my point in this paper, on an understanding of Norwegian theatre history, nor a study of the actual audience and population of Ibsen's contemporary Christiania. The negative opinion of Ibsen's theatre repertoire and the high audience attendance for $A$ Caprice and other productions is only a result of an established, Kantian pattern of understanding of art.

\footnotetext{
${ }^{6}$ Bourdieu 1984.
} 


\section{THEATRE IN NORWAY WAS PRIMARILY AN UPPER CLASS ACTIVITY}

The first theatres in Norway were founded as dramatic societies in the major cities and towns along the coast in the period $1780-1830$. According to Anette Storli Andersen, the members of these societies were recruited from the economic and intellectual elite, and the societies were important elements in establishing a public sphere in Norway. ${ }^{7}$ The leading members of the constitutional assembly in 1814 were all members of dramatic societies. This was definitely a highbrow activity. The members of the dramatic societies established and ran rather large and very well equipped theatre buildings. The largest, like the theatre in Bergen where Ibsen started his theatrical career, were actually better equipped and more modern than the contemporary royal theatres in Stockholm and Copenhagen. Ibsen was, therefore, as also underlined by Ellen Karoline Gjervan, disappointed with the stage machinery when he, in 1852, visited the Royal theatre in Copenhagen. ${ }^{8}$

The members of the dramatic society managed the theatres and were also responsible for the staging of the performances. Additionally, all members had an obligation to participate as actors. The fact that the members were both the audience and the actors has generally been an argument for an evaluation of the dramatic societies as an amateur activity. Andersen argues, however, that the reason why the members had the duty to act was because the dramatic societies were established to educate the members in "pleasant and utilitarian" practises. ${ }^{9}$ In the running of the theatre building and the dramatic society, the members were trained to subordinate their personal will for the common interest. As audience, they were also the internal critics. ${ }^{10}$ As actors, they were both training their reason and feelings and their bodily appearance and behaviour. Quite contrary to Kant's understanding of the relation between action and reading, feeling and reflection, Andersen, with references to the late eighteenth-

\footnotetext{
7 Andersen 2010a; 2010b; 2013; and 2014.

Gjervan 2010.

9 Andersen 2010a and 2015.

${ }^{10}$ Andersen and Nygaard 2008.
} 
century writings of Rothe ${ }^{11}$ and Rahbek ${ }^{12}$ and later interpretations of $\mathrm{Mai}^{13}$ and Damsholt, ${ }^{14}$ has underlined that in the cultural elite there was a general distrust to written accounts. Sensuous experience had a much stronger impact on the moral than reading. Enlightenment was, according to Rothe, about improvement of both reason and feeling, and feelings were especially improved by the performing arts. The improvement of the member's feelings was also the reason why Rahbek underlined the importance of the dramatic societies for developing the society in general.

Andersen has described the impressive extent of the dramatic societies. The activity engaged almost all members of the urban upper class in towns and cities. The theatre venues were adapted to the number of members, from 200300 in the smaller towns and more than 1000 in the two larger cities, Bergen and Christiania.

After the Napoleonic wars, almost all members of the patrician upper class, which had founded and actively contributed to the dramatic societies, went bankrupt. The historian, Finn-Einar Eliassen, has compared this dramatic change to the head being cut off from the Norwegian towns. ${ }^{15}$ After the fall of the former upper class, the theatre buildings of the dramatic societies were rented out to touring Danish troupes. In the new capital of Norway, Christiania, the first efforts to establish permanent, public theatres were made in 1827, only to become bankrupt in the following year. A new institution, Christiania Public Theatre (Christiania Offentlige Teater), took over and later, the Christiania Theatre opened in a new theatre building in 1837 with Danish actors and under Danish management. The idea of a permanent Norwegian Theatre with Norwegian actors and a Norwegian repertoire was manifested in Bergen in 1850, two years later in Christiania, and around 1860 in Trondheim.

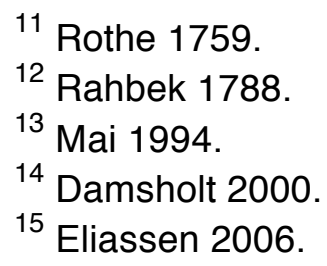


In the period of the dramatic societies, members of the upper class gave their peers all the functions of the theatre, including administration, acting, and directing. They also served both as internal critics and as audience. What had been a unified, unique, and blurred field was, after the fall of the former upper class, separated in different professions and functions: administration, acting, and directing, audience - and critics. In the first step of this development, the actors and directors were also the managers, as was also the case with the touring Danish troupes. The founder of the first public theatre in 1827, manager, director, and actor Johan Strömberg was also the owner of the theatre. ${ }^{16}$ With the Christiania Theatre and the Norwegian theatres in Bergen and Christiania, the theatres had a professional administration and management, and employed actors and directors. The professionalization of the theatres was again met with the professionalization of the critics in the newspapers.

The relationship between critics and the theatre management was at first close, almost like the relationship between the internal critics of the dramatic societies and the directors and actors. The first professional director, Strömberg, for example, actually adjusted the performance in accordance to the criticism received. ${ }^{17}$ Later, the role of the critics was detached - as observers and there was a clearer distinction between the theatres and the critics. The critics first of all discussed the text and evaluated the performance as a presentation of the text. This was also Ibsen's perspective when he started as a critic in the early 1850s. When he had become a director and manager in 1861, Ibsen wrote a series of articles about the two theatres in Christiania, arguing against the critics and their constant focus on what he called, the raw material dogma (Raastofs/æren) or the un-artistic question of what was staged - the repertoire - instead of the artistic question of how it was staged - the performance. $^{18}$

\footnotetext{
${ }^{16}$ Anker 1958.

17 Andersen and Nygaard 2008.

${ }^{18}$ Henrik Ibsen 1928-, XV, 258-259.
} 
The founder of the Norwegian Theatre in Christiania, Johannes Klingenberg, was a military officer in the engineer corps and is generally known as the 'father' of modern waterworks in Norway. After a visit off duty to Bergen, he was so disappointed with the repertoire and acting style of the Norwegian Theatre in Bergen that he initiated a theatre school in Christiania. The performances of the theatre school subsequently formed the foundation for the Norwegian Theatre in Christiania. Klingenberg's idea for a Norwegian theatre was in accordance with the idea behind the dramatic societies: In order to aid Norway's development, it was not only important to develop a technical infrastructure, but also to form an ideological and cultural structure. Klingenberg therefore invited onto the board of the theatre the 'father' of the modern Norwegian language, Knud Knudsen. Later, other scholars and important cultural personalities were included on the board, such as university Professor of Aesthetics Jacob Monrad, who, in 1854, had published an article about theatre, nationality, and a Norwegian theatre school in which he underlined, as with the dramatic societies, the importance of theatre as an institution of education. ${ }^{19}$

In his survey of the repertoire of the Norwegian Theatre in Christiania 18521863, Øyvind Anker also included the members of the board. ${ }^{20}$ The board of the Norwegian theatre in Christiania included military officers, lawyers, and higher civil servants and, from the very beginning, the board, most interestingly, also included private entrepreneurs, founders of the new financial institutions, banks and insurance companies as well as industrial enterprises. The founders of what should be the largest textile factory in Norway, the largest engineering and construction firm, ironwork, match factory, brewery, detergent producer, and brickyard were also all members of the board of the theatre.

In other words, the elite of the Age of Enlightenment had, at the end of the eighteenth century, established theatre in Norway by means of the dramatic societies. Norwegian theatres were again, after 1850 , established and run by a new elite, based on the same ideology and the same principles as with the dra-

\footnotetext{
${ }^{19}$ Monrad 1854, 1.

${ }^{20}$ Anker 1956.
} 
matic societies. The only difference was that the staging and acting was performed by a new group of professionalized artists. The important question is, however, who was the audience? Was it still the elite, the highbrow audience, or was the theatre also attracting a new, lowbrow audience - as suggested by contemporary and later critics of $A$ Caprice.

\section{THE DEVELOPMENT OF CHRISTIANIA AND ITS AUDIENCE}

To understand the development of Christiania and its audience, it is necessary to underline an important fact: for almost 400 years until 1814, Copenhagen had been the capital of Norway. All the important political, social, and cultural institutions were located in Copenhagen. Christiania was not only a minor town compared with Copenhagen, but also compared with other Norwegian towns especially Bergen, which, since the Middle Ages, had been the largest city in Norway. The inhabitants of Christiania before 1814 were - just like in other similar Norwegian towns like Trondheim, Drammen, or Ibsen's town of birth, Skien, first of all a group of wealthy timber exporters and merchants and their families. To underline the radical change of Christiania in 1814, the historian, Jan Eivind Myhre, has given his study of the transformation of Christiania the subtitle "Ravnekrok blir hovedstad" ${ }^{21}$ - the godforsaken place becomes capital.

In his main work on the capital Christiania 1814-1900, Myhre gives a detailed presentation of how the former small town Christiania radically changed status and became the new national centre of administration, learning, banking, trade - and, later, industry. ${ }^{22} \mathrm{~A}$ new fast-growing elite emerged in the town, composed of higher governmental civil servants, university professors, bankers, and merchants. This elite was recruited, as had the earlier elites, both from immigrants from Denmark, Northern Germany, Holland, and England as well as outsiders moving to Christiania from other parts of Norway. During its first period of growth, Christiania therefore had, first of all, a growing elite population in the city centre and a relatively slower growth of craftsmen and shopkeepers

${ }^{21}$ Myhre 2016.

22 Myhre 1990. 
in the suburbs. Based on the public censuses, the population was doubled in the twenty years from 1835 to 1855 . Then, after the industrialisation turned from small scale to large-scale enterprises in the second half of the nineteenth century, the working-class population in Christiania, especially in the suburbs, exploded and Christiania was, in the period $1855-1880$, the fastest growing city in Europe. ${ }^{23}$

Relevant to my topic, Myre asks an important question in his presentation of Christiania in the 1850s: "Finnes arbeideren?"24 - Does the worker exist? The reason for his question is the fact that the working force and the lower classes in Christiania were actually not settled in the city, but commuted or moved temporarily in and out from the surrounding districts as their employment in Christiania was dependent on the season and shifting job opportunities.

The survey of the population in Christiania in relation to position (Stand) and employment (Næringsvel) in the public census of 1855 reveals some interesting facts. ${ }^{25}$ The standard categories are merchants (Handelsmenn), factory owners (Værkseier, Fabrikanter), craftsmen/artisans (Haandværkere), shipmasters (Skippere), Sailors (Sjøfarende), day workers (Daglønnere), servants (Tjenestefolk) and people not relevant to any of the mentioned categories (Personer der ikke kan henfores under nogen av de nevnte Klasser). For all categories, a distinction is made between the principal character (that is the family father) and the family, except for servants where a distinction is drawn between male and female. Furthermore, the category of people not relevant to any of the specified categories is numbered without any further distinction. Of these categories, the first four are generally understood to be the citizens (Borgere), or the upper classes, and the next three categories as the lower classes.

The largest numbers in specified categories are the family members of the day workers, a total of 3529 , followed by female servants with 3128 . The largest category for the main persons is that of day workers. All this seems to fit per-

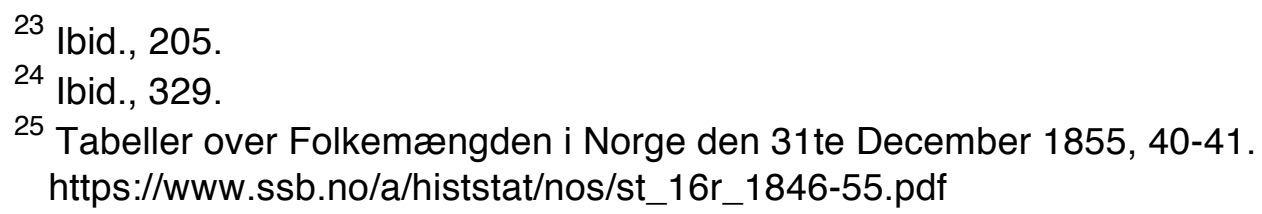


fectly into a supposed distribution of the inhabitants with a majority of day workers and female servants. But this was not the case in Christiania of 1855. By far the largest category was the unspecified category of persons, which could not be included in any of the established categories. As many as 16837 persons, or $53 \%$ of the total population of 31715 in Christiania in 1855, obviously neither belonged to any of the established categories - nor to any of the new categories of industrial workers as no large-scale industry was yet established, and the total number of factory owners in Christiania in the 1855 census was 0 - zero. The majority of the population was, therefore, associated with the new upperclass positions of the capital - civil servants, lawyers, bankers, professors, managers, and their families.

According to the public census, the total number of persons belonging to the categories of the lower classes in Christiania in 1855 was 9388 - or $29,6 \%$ of the total population. Which means that $70,4 \%$ of the population can be understood as being members of the middle or upper classes. This means again that the seemingly incredible high attendance for $A$ Caprice of $67 \%$ of the population was actually within the limits of the portion of the middle and upper classes in Christiania in 1855.

This indicates that the 'lower' classes in Christiania in the 1850s were unimportant as a potential audience for the theatres. To achieve success, the theatres in Christiania, in the 1850s, did not have to stage a lowbrow repertoire in order to attract a lower-class audience. The best way to raise the number of attendances was to attract a large proportion of the highbrow audience that the theatre already had. Therefore, the reason for the success of $A$ Caprice was that Ibsen was able to attract a large proportion of the members of the middle and upper classes in Christiania. In addition to the permanent inhabitants, there was a relatively large number of soldiers and students living in Christiania, which were not registered as inhabitants in the city and, of course, there would be a certain number who attended the production more than once. All this underlines the fact that the seemingly incredibly high number of attendances for the production, A Caprice, was actually not that incredible at all. 


\section{THE DEVELOPMENT OF A LOWER CLASS AUDIENCE IN CHRISTIANIA}

The census of 1865 gives quite another picture of the potential theatre audience in Christiania. ${ }^{26}$ First of all, the number of inhabitants had almost doubled since 1855 from 31715 to 57382 . In addition, the categories in the census were revised. The large category of people, which were not included in the established categories in the 1855 census, was, in 1865, split into new categories. Two of the new categories were immaterial work (Immaterielt arbeid) and non-productive work (Ikke produktivt arbeid). The first category included all kinds of academic and scholarly work. The other category included all who lived by their economic capital as their interest income, dividends, or the stock market. In total, these two categories constituted $25 \%$ of the population. In addition the category commerce and trade (Handel, skipsfart) constituted $20 \%$ of the population. In sum, only $45 \%$ of the 1865 population could be understood as being middle or upper class. On the other hand, a large new working class category, mining and industry (Grubedrift og industri), constituted about $45 \%$ of the population. In other words, in the $1860 \mathrm{~s}$, Christiania changed radically from being a city with a middle and upper-class majority to a city with a larger and larger proportion of 'lower' class or industrial working-class inhabitants. This change had an immediate influence on the theatre system in Christiania and the relation between theatre and, other forms of culture and entertainment.

The history of the venue of the Christiania Norwegian Theatre is, in itself, an interesting example of the development of a lower class audience in Christiania. The venue was originally opened in 1847 as Løven (the Lion) intended to be a dance hall for the lower classes. This was obviously too early to attract a real lower class of young men. It was in Christiania, however, that a larger number of young girls worked as maidservants in upper-class homes. Instead of being a dancing venue for the lower classes, the dance hall became a meeting-place for young maidservants and young men from the upper class. After a series of

${ }^{26}$ Resultaterne af Folketællingen i Norge i januar 1866, 123. 
strong moral complaints, the dance hall was forced to close in 1852 and the Norwegian Theatre in Christiania rented the venue. ${ }^{27}$

In the 1850s, the Norwegian Theatre in Christiania obviously attracted the same middle and upper-class audience as the Christiania Theatre. The board therefore decided to buy the theatre venue and to reconstruct the theatre to retrain its upper-class audience in competition with Christiania Theatre. However, because expenses grew higher than its income, the theatre ran into an economic crisis and went bankrupt in 1862.

After the Norwegian Theatre in Christiania went bankrupt, a new theatre institution, Christiania Folketeater (Christiania Popular Theatre), took over the venue. This was a 'Folketeater' in the meaning 'popular' and different companies, presenting light entertainment and musical comedies for the fast growing middle and lower class audience, hired the venue.

In the 1860s, there was, however, still no market for lowbrow theatres in Christiania, which could, for example, present variety shows with a large chorus of dancing girls. The change came in 1877 when the amusement- and entertainment-park, Christiania Tivoli, opened in the working class suburb district of Piperviken. In 1890, the Circus Theatre opened in Tivoli presenting cabarets and large variety shows in addition to circus performances. By far the greatest success of the new entertainment theatres was the show Tutti Frutti at Eldorado Theatre, which was performed 101 times in 1893 in a theatre hall with almost 2000 seats. It achieved an attendance of about $80 \%$ of the population of Christiania. This was really amusement for the lower classes and, for this production, lowbrow performance and a lowbrow audience are undoubtedly relevant terms.

In 1859 , however, it was not relevant to understand the $70 \%$ or more of the population in Christiania attending $A$ Caprice due to it being an amusement for the lower classes because, at that time, the lower classes could hardly be said to have existed in Christiania. A Caprice was, therefore, intended as amusement for the upper classes.

\footnotetext{
${ }^{27}$ Collet 1909, 382
} 
The reason for my distinction between the two audience success productions in 1859 and 1893 is the development and change in the population that can be documented in the public censuses. The census of 1900 had very refined categories compared with the census of $1855 .{ }^{28}$ It is, therefore, possible to give more detailed studies of the potential audience for theatre and entertainment in 1900. The total population in Christiania in 1900 was more than seven times larger than in $1855-229101$ in relation to 31715 .

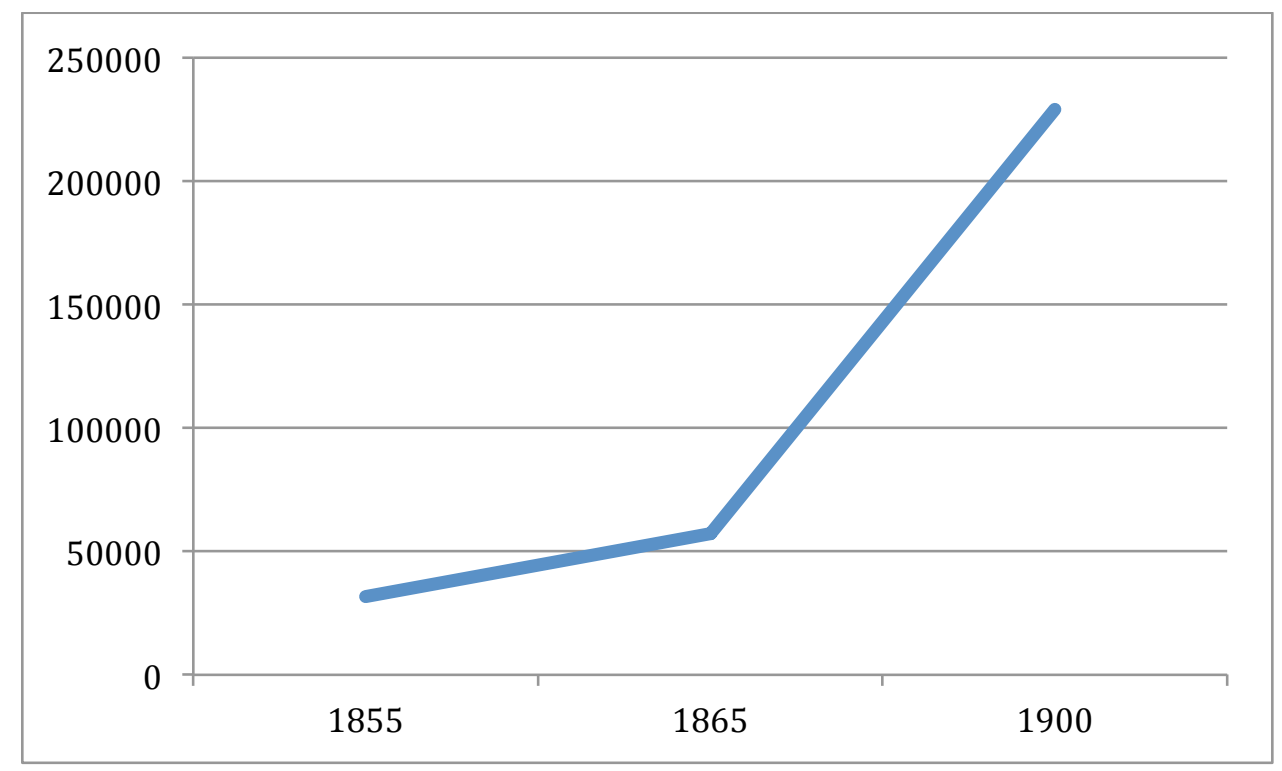

Figure 1: Growth of the total population in Christiania 1855-1900

In addition to the growth, the distribution between the different classes and social groups had changed considerably. Most obvious is the relation between the civil servants, who had been a relatively large and important group after 1814 , and the industrial workers, who had not existed as a social group in Christiania before the 1860s. In 1900, the total number of civil servants was almost the same as in 1855. With their families they numbered 3496, but their proportion of the total population was only $1,5 \%$. On the other hand, at the same time, industrial workers with their families amounted to a total of 113182 persons or almost $50 \%$ of the population.

Another indicator for the change is that between 1855 and 1900 the total number of servants had dropped. This decrease was most obvious in the case

\footnotetext{
${ }^{28}$ Norges officielle Statistik 1905.
} 
of maidservants who were more than 3000 in 1855, but only a little more than 1000 in 1900. This means that the former upper class had been scaled down and that young women had been given other job opportunities. The most important job opportunity was in the textile and match factories and the category industrial worker was, in the census, the most important position for women. In other words, in 1900, the former civil servant and upper-class city of Christiania changed to being a predominantly industrial one.

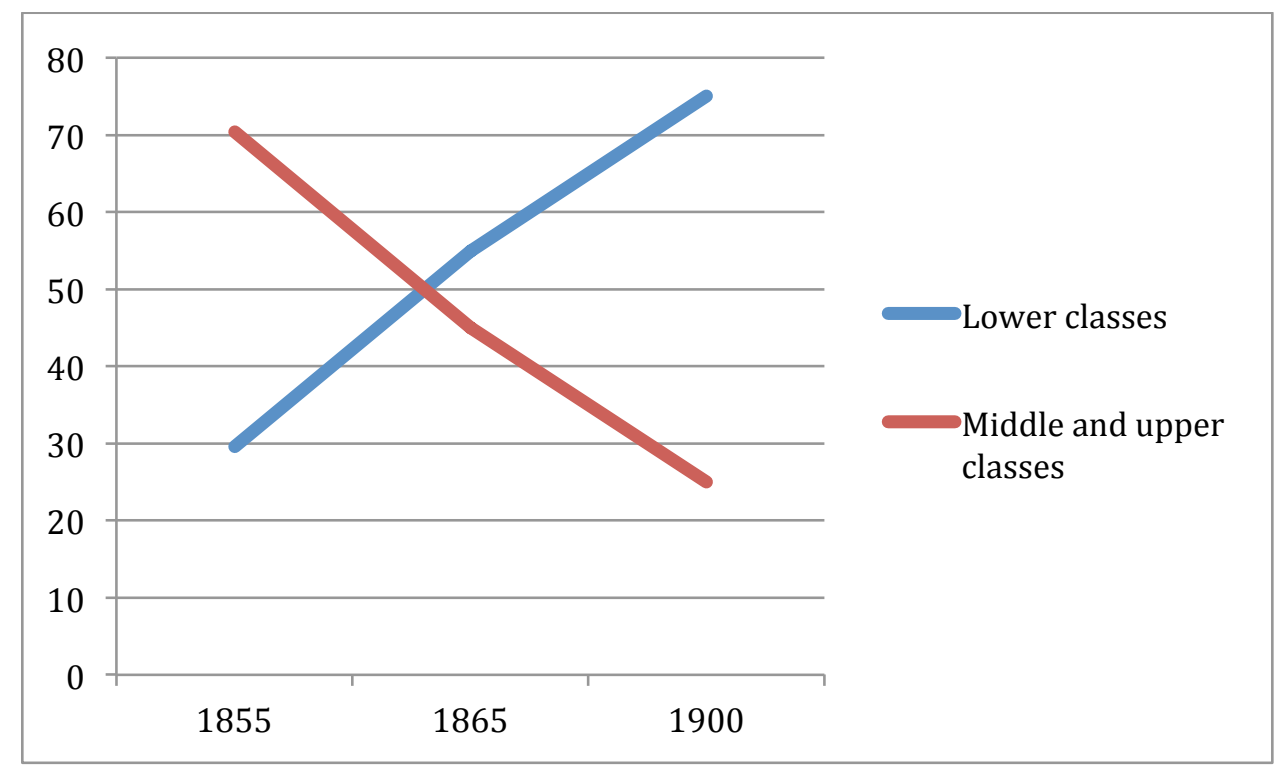

Figure 2: Relation between the proportion of upper and lower classes in Christiania 1855-1900

If we sort the population of Christiania in 1900 according to their social positions into upper, middle, and lower-class categories, the upper-class position as selfemployed, business, and tradesmen, which numbered 26 249, was the largest following the group of industrial workers. If we also add to the 'upper' class other self-employed groups, civil servants, and persons who live from their property, profit or dividend, the total number of the upper-class, including their families, was around 50000 or $25 \%$ of the population. Which means that more than 150000 or $75 \%$ of the population in Christiania in 1900 belonged to the middle or lower classes. This was the complete opposite of the situation in 1855 when at least $75 \%$ belonged to the upper or middle classes and only $25 \%$ of the population could be understood as 'lower' class. 


\section{CONCLUSION}

Based on Bourdieu's critique of Kant, I have, in this article, discussed the relevance of the categories 'highbrow' and 'lowbrow' and found that they are irrelevant, or misleading if they are not related to a social context. As in the case of Ibsen's production of $A$ Caprice in Christiania in 1859, a record large audience number is not necessarily an indicator for a 'lowbrow' production. Audience numbers are in themselves not enough to draw conclusions. We have, in addition, always to ask the question: Who is actually behind the audience number? Who is - or could be - the audience?

Given the social structure of the Norwegian capital in the 1850s, I have argued that it was unlikely that the production of $A$ Caprice could attract a large lower class audience because during this period what can be understood as a lower class hardly existed in Christiania. Therefore, the production could only be successful because it attracted a large proportion of the upper and middle-class majority of Christiania.

In the 1860s, the population of Christiania changed, and in 1900 the situation was the opposite of the 1850s. Christiania had gained a lower and middle class majority and an upper class minority. A large success in the theatre, especially in the variety halls, needed accordingly to be based on the majority of the population - the 'lower' classes - and the category 'lowbrow' can, in this context, be relevant for studying the most successful productions.

\section{References}

Andersen, Anette Storli. 2010a. "Deus ex machina? Henrik Ibsen og teatret i norsk offentlighet 1780-1864." PhD thesis. Oslo University.

Andersen, Anette Storli. 2010b. "Theatrical Worldmaking. How the Norwegian Constitution was Prepared within the Theatre." Birgit Neumann, Ansgar Nünning and Vera Nünning (eds.). The Aesthetic and Politics of Cultural Worldmaking. Giessen Contributions to the Study of Culture 3. Trier: Wissenschaftlicher Verlag, 49-62. 
Andersen, Anette Storli. 2013. "Teatret og Riksforsamlingen i 1814. De handlende personers kunst.” N. Langeland (ed). Politisk kompetanse: Grunnlovas borgar 1814-2014. Oslo: Pax, 280-303.

Andersen, Anette Storli. 2014. "“Enige og troe til Dovre falder”: Om iscenesettelsen av en klippefast nasjon." Nordisk tidskrift för vetenskap, konst og industri. 90: 2, 167-174.

Andersen, Anette Storli. 2015. "Theatre, patriotism, and politics in DenmarkNorway, 1772-1814." Ellen Krefting, Aina Nøding and Mona Ringvej (eds.). Eighteenth-Century Periodicals as Agents of Change: Perspectives on Northern Enlightenment. Leiden \& Boston: Brill, 215-235.

Andersen, Anette Storli and Nygaard, Jon. 2008. "Teaterkritikkens utvikling fra 'innvendig' til 'utvendig'. Hvilke institusjonelle forhold har ligget til grunn for tilblivelsen og utøvelsen av teaterkritikk i Norge?" Paper presented at Tyrifjordseminaret 8.5-9.5.2008. Program for aesthetic studies, University of Oslo.

Anker, Øyvind. 1956. Kristiania Norske Theaters Repertoire 1852-1863. Oslo: Gyldendal, 1956.

Anker, Øyvind. 1958. Johan Peter Strømberg. Mannen bak det første offentlige teater i Norge. Oslo: Gundersen 1958.

Bourdieu, Pierre. 1984. Distinction: A Social Critique of the Judgement of Taste. Translated by Richard Nice. London \& New York: Routledge.

Collet, Alf. 1909. Gamle Christiania-billeder. Christiania: Cappelen.

Damsholt, Tine. 2000. Fædrelandskærlighed og borgerdyd. Patriotisk diskurs og militære reformer i Danmark i sidste del av 1700-tallet. Copenhagen: Museum Tusculanum.

Eliassen, Finn-Einar. 2006. Småbyenes storhetstid ca. 1500-1830. Oslo: Pax.

Gjervan, Ellen Karoline. 2010. "Creating Theatrical Space: A Study of Henrik Ibsen's Production Books. Bergen 1852-1857." PhD thesis. University of Bergen.

Ibsen, Henrik. Samlede verker. Hundreårsutgave. Oslo: Gyldendal. 1928-57

Lund, Audhild. 1925. Henrik Ibsen og det norske teater. Oslo. Malling.

Mai, Anne-Marie. 1994. Moralske fortællinger 1761-1805. Copenhagen: Borgen.

Meyer, Michael. 1971. Ibsen: A Biography. Garden City, NY: Doubleday.

Monrad, Marcus Jacob. 1854. "Om Theater og Nationalitet og om en norsk dramatisk Skole." Norsk Tidskrift for Videnskab og Litteratur 7, 1-33.

Myhre, Jan Eivind. 1990. Hovedstaden Christiania: Fra 1814 til 1900. Oslo: Cappelen.

Myhre, Jan Eivind. 2016. Christiania 1814. Ravnekrok blir hovedstad. Oslo: Akademisk publisering. 
Norges officielle statistik. Fjerde Række Nr. 111. Folketællingen I Kongeriget Norge 3 December 1900. Femte Hefte. Folkemængde fordelt efter Livsstilling. Udgivet af Det statistiske Centralbureau. I kommission hos H. Aschehoug \& Co, Kristiania 1905.

Rahbek, Knud Lyne. 1788. "Om Privattheatrenes Bestemmelse, Nytte, og Skade." K. L. Rahbek (ed.). Dramaturgiske Samlinger 1. Copenhagen: Johan Frederik Schultz.

Resultaterne af folketællingen i Norge i januar 1866. Udgivne af Departementet for det Indre. Trykt i det Steenske bogtrykkeri, Christiania 1869.

Rothe, Tyge. 1759. Tanker om Kiærlighed til Fædernelandet. Copenhagen: Nicolaus Møller.

Svarstad, Elisabeth and Nygaard, Jon. 2016. "A Caprice: The Summit of Ibsen's Theatrical Career.” Ibsen Studies 16:2, 168-185. DOI: 10.1080/15021866.2016. 1263445

Tabeller over Folkemængden i Norge den 31te December 1855. https://www. ssb.no/a/histstat/nos/st_16r_1846-55.pdf

\section{AUTHOR}

Jon Nygaard holds a master degree (magister) in literature, University of Oslo 1969 and was a research fellow at the University of Oslo 1970-72. He was appointed Ass. Professor in drama and theatre, University of Trondheim 1973-75, Assoc. Professor in Theatre Studies, University of Trondheim 1975-83 and at the University of Oslo 19842001, and Professor in Theatre Studies 2001-16, University of Oslo, Centre for Ibsen Studies. Nygaard holds a Diploma in directing from Reinhardt Seminar, Vienna 1982. 